\title{
Langerhans Cell Histiocytosis in the Chest Wall
}

\section{Göğüs Duvarında Langerhans Hücreli Histiyositoz}

Muharrem Çakmak', Adile Ferda Dağlı

\section{Abstract}

Langerhans Cell Histiocytosis (LCH) refers to a nonneoplastic proliferation of Langerhans cells with an incidence in the adult population of 1-2 per million. It is considered a pediatric disease, and while rib involvement is very rare, we report here on a 33year-old patient with LCH located in the rib.

Key words: Chest wall, Mass, Langerhans cell tumor, Eosinophilic granuloma.

\section{Özet}

Langerhans Hücreli Histiyositoz (LCH), Langerhans hücrelerinin neoplastik olmayan bir proliferasyonudur. Erişkinlerde insidansı milyonda 1-2 'dir. Pediatrik bir hastalık olarak kabul edilir. Kot tutulumu çok nadirdir. Çalışmamızda, kotta yerleşim gösteren 33 yaşındaki LCH olgusunu sunuyoruz.

Anahtar Sözcükler: Göğüs duvarı, Kitle, Langerhans hücreli tümör, Eozonofilik granuloma.
'Department of Thoracic Surgery, Firat University Faculty of Medicine, Elazığ, Turkey

${ }^{2}$ Department of Pathology, Firat University Faculty of Medicine, Elazığ, Turkey
'Fırat Üniversitesi Tıp Fakültesi, Göğüs Cerrahisi Anabilim Dalı, Elazı̆g

${ }^{2}$ Fırat Üniversitesi Tıp Fakültesi, Patoloji Anabilim Dalı, Elazığ

Submitted (Başvuru tarihi): 02.08.2020 Accepted (Kabul tarihi): 14.09.2020

Correspondence (iletişim): Muharrem Çakmak, Department of Thoracic Surgery, Fırat University Faculty of Medicine, Elazığ, Turkey

e-mail:drcakmak@gmail.com

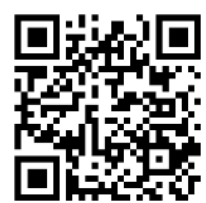


Langerhans Cell Histiocytosis $(\mathrm{LCH})$ is a non-neoplastic proliferation of Langerhans cells (1), of which the etiology is unknown. It is characterized by an accumulation of Langerhans cells (LC) in various tissues and organs, with an incidence in the adult population of 1-2 per million. It is considered a pediatric disease (2). The involvement of single or multiple organs can be seen, although rib placement is rare (3). Local pain is the most common symptom, and diagnosis is through biopsy. The optimum treatment depends on the age of the patient, the localization of the lesion, the number of lesions and the size of the lesion (4). In the present study, we report on an adult patient with LCH (Eosinophilic Granuloma) in the rib.

\section{CASE}

A 33-year-old male patient was admitted to our clinic with a painful swelling to the chest wall that had gradually increased over the last year. A physical examination of the patient revealed a painful mass measuring $15 \times 35 \mathrm{~mm}$ in the inferolateral aspect of the right hemithorax. A chest $X$-ray revealed an irregularity in the lateral of the 8th rib, along with a thickening of the pleura.

A thorax tomography of the patient revealed a mass lesion invasive to the parietal pleura in the lateral of the 8th rib, as well as multiple millimetric pulmonary nodules in the bilateral lungs (Figure 1). A positron emission tomography of the patient revealed hypermetabolic activity in the mass lesion in the lateral of the 8th rib (SUVmax: 7.9) (Figures 2).

Laboratory tests revealed elevated Glucose (129 mg/dL), Creatine Kinase (CK: 464 U/L), CK-MB (Creatine KinaseMB: 36U/L), C-Reactive Protein (CRP: 96mg/L) and White Blood Cell (WBC: 12.43 10e3/ $\mu \mathrm{L}$ ) levels, and low Lymphocyte $(1.1910 \mathrm{e} 3 / \mu \mathrm{L})$ and Total protein $(6 \mathrm{~g} / \mathrm{dL})$ levels.

In the planned operation, the mass was observed to have invaded the pleura and the surrounding tissue, and was excised to include intact bone and pleural tissue (Figures 3). The defect in the chest wall was reconstructed with mesh and a titanium plate to prevent flail chest or collapse (Figure 4, 5a, b). The pathology report identified $\mathrm{LCH}$ (Eosinophilic Granuloma). Surgical margins were negative (Figures 6a, b, c).

After the pathological diagnosis, a hematology consultation was requested, and brain magnetic resonance imaging (MRI) was requested by the Hematology Department, but came up normal. A bone marrow biopsy was performed by hematology. In the bone marrow cytology, in mature myeloid series, in eosinophils, in megakaryocytes and in dysmegakaryopoiesis were detected increasing. The results of the biopsy reported normocellular bone marrow. The follow-up and treatment of the patient continued with hematology. The patient was followed up for around one year, during which no complications were seen.

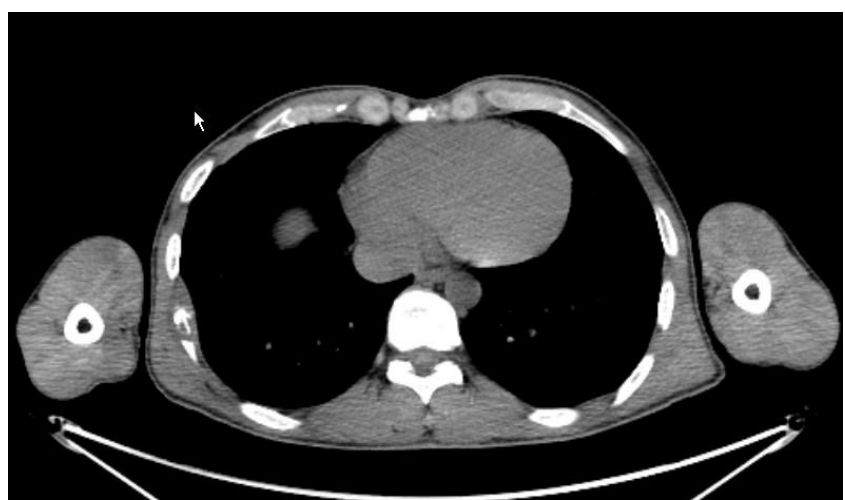

Figure 1: Tomography image of the patient

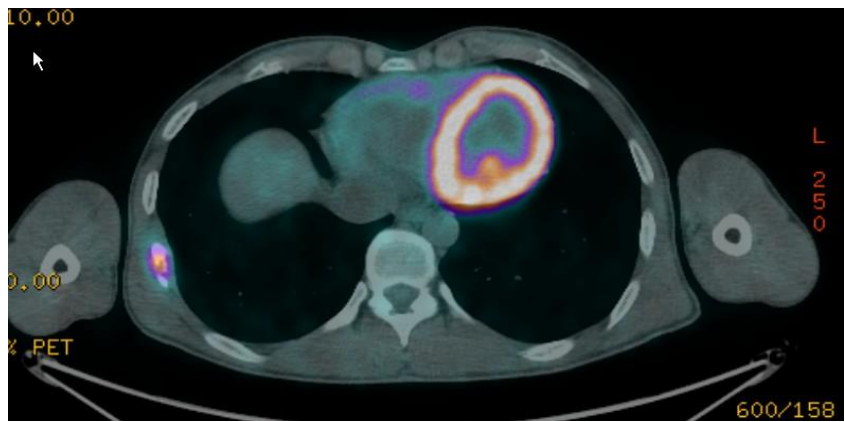

Figure 2: PET-CT image of the patient (axial)

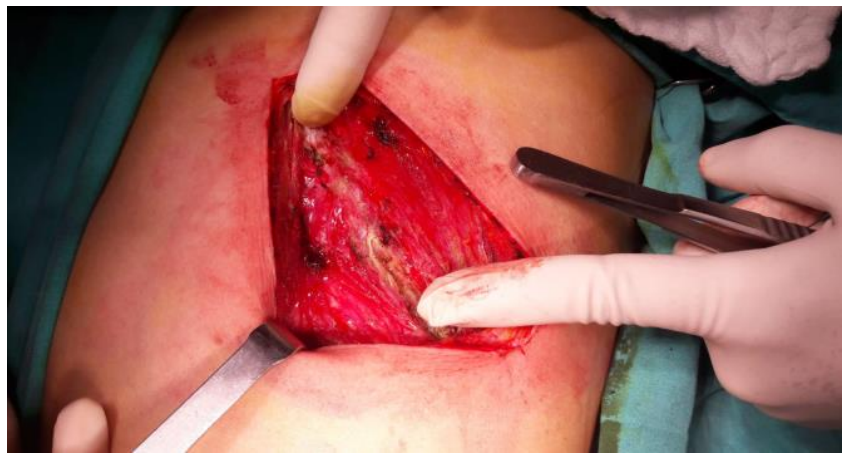

Figure 3: Intraoperative image of the mass

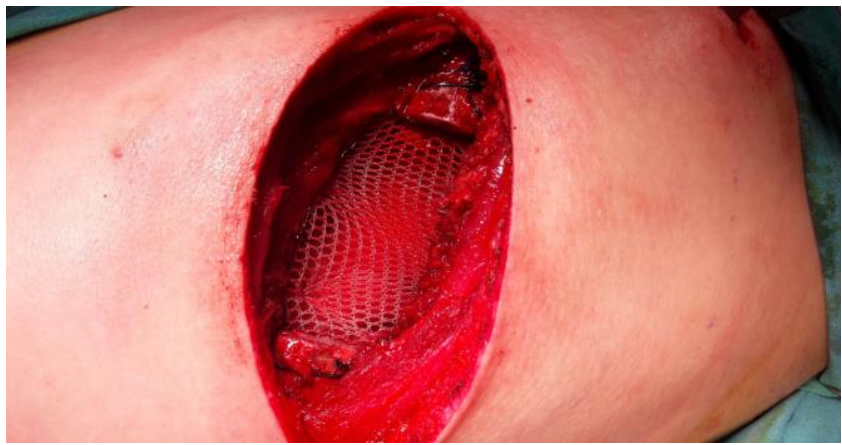

Figure 4: Mesh support of surgical area 

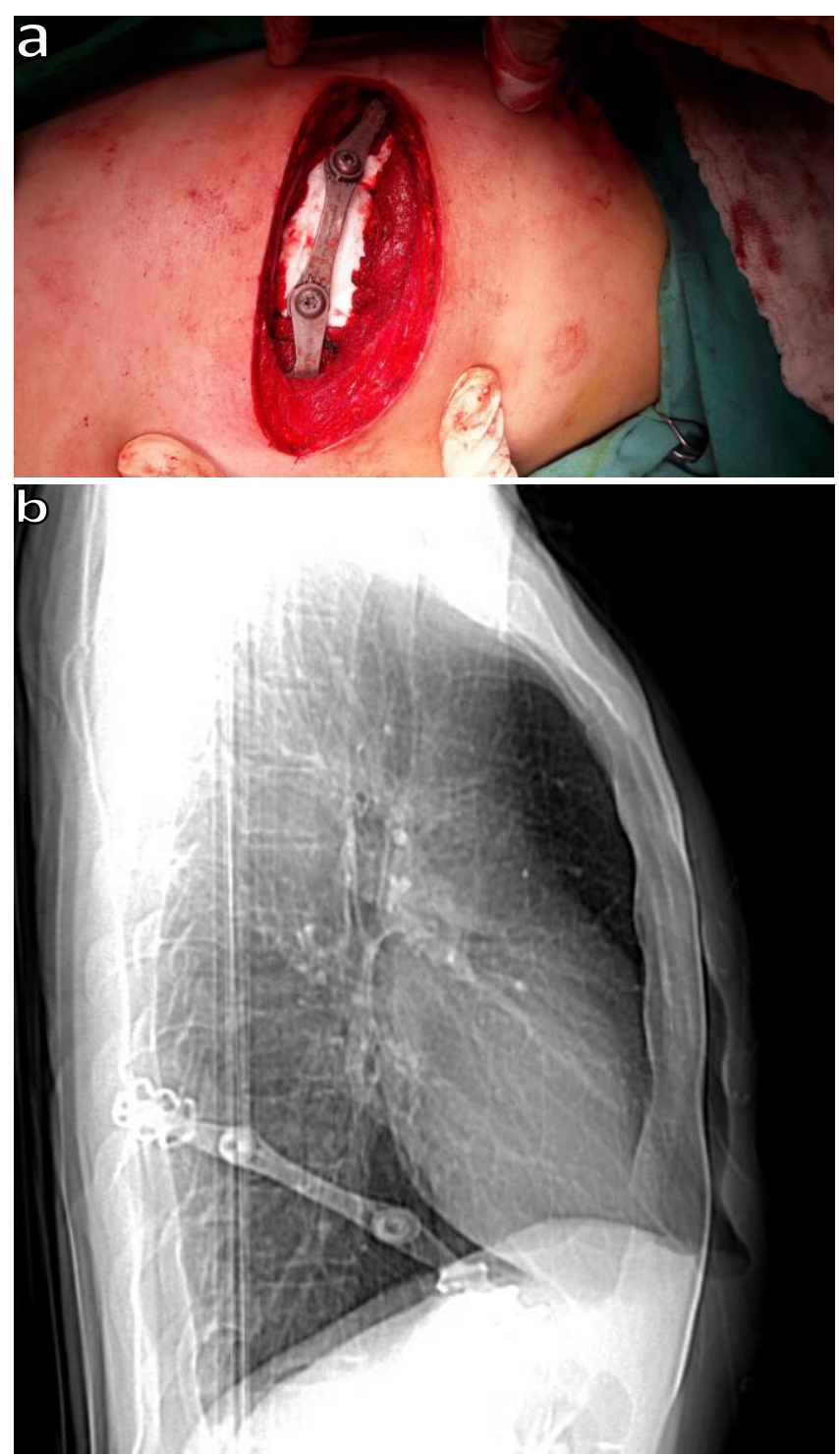

Figure 5a and b: Reconstruction of the area with artificial ribs (a), postoperative lateral chest radiography (b)

\section{DISCUSSION}

$\mathrm{LCH}$ is a rare disease that causes local or systemic effects with proliferation and infiltration of histiocytes in various organs (2). The etiology offers no definitive evidence of any infective agent, metabolic or genetic factor, or immunodeficiency (5), and there was no etiological cause also in our patient. The disease generally occurs in the $35 \pm 14$ age group (1). The patient in the present study was a 33-year-old male.

LCH has been classified into two groups by the Histiocyte Society Working Group as a single-system or multiplesystemic disease. It can be expressed as low-risk or highrisk, depending on the involvement of such organs such as the liver, spleen, lung and hematopoietic system. LCH, Hashimato-Pritzker disease, Hand-Schuller-Christian disease, eosinophilic granuloma and Letterer-Siwe disease present with four different clinical pictures, although all of these diseases due are referred to as $\mathrm{LCH}$ due to their common immunological features $(3,6)$.

Hashimato-Pritzker's disease is characterized by reticulohistiocytosis; Hand-Schüller-Christian is a chronic disease that is characterized by four findings: bone lesions, diabetes insipitus, exophthalmos and mucocutaneous lesions; Eosinophilic granuloma accounts for less than 1\% of all bone tumors, and $90 \%$ of patients are under the age of 10 years. It usually involves the head and vertebral bones, and takes the form of a single lytic lesion. The presence of Langerhans cells is pathognomonic. Letterer-Siwe disease is an aggressive, systemic and often fatal histiocytosis that occurs usually in infancy or early childhood (7).

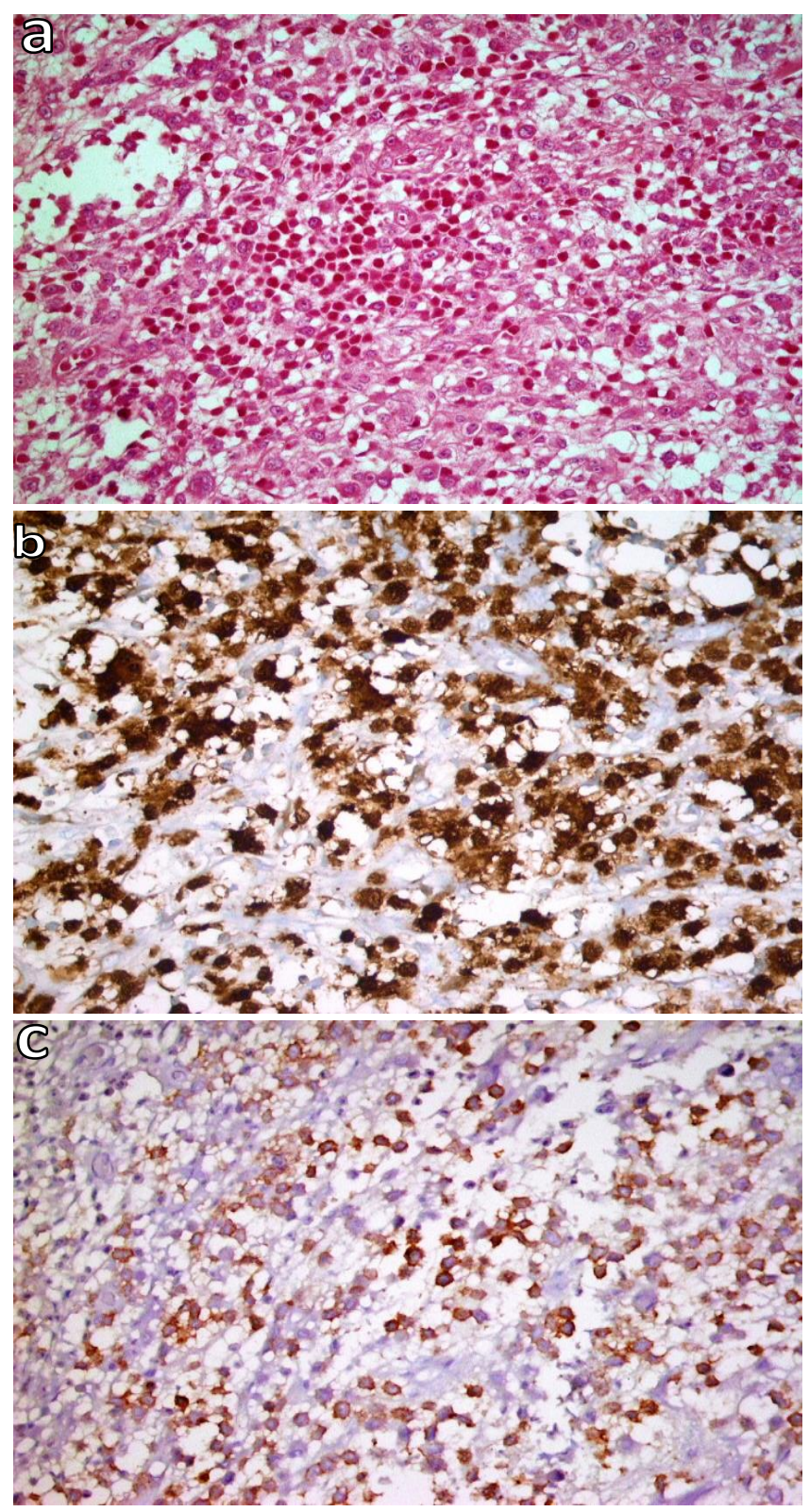

Figure 6a, b and c: Langerhans cell histiocytosis consisting of histiocytes, lobulated nucleated Langerhans cells and eosinophils (H\&Ex400) (a), S-100 positivity in Langerhans cells (x400) (b), CDla positivity in Langerhans cells (x400) (c) 
The symptoms in $\mathrm{LCH}$ vary depending on the organ involved (1). Local pain is the most common symptom (34\%), although other common symptoms include weight loss $(11 \%)$ and fever $(10 \%)$. The main complaints of our patient were pain and swelling.

Bone lesions are most commonly seen in the skull (51\%), although other sites of involvement include the jaw (30\%), long tubular bones (17\%), vertebrae (13\%), pelvis (13\%) and ribs (6\%) (1). Single-zone, single-system LCH in the rib is a rare condition in adults, and can be difficult to predict (2).

The radiological appearances of $\mathrm{LCH}$ are not specific, although the most common findings are osteolytic and sclerotic bone structures. Differential diagnoses include metastasis, plasmacytoma, multiple myeloma, aneurysmal bone cysts, fibrous dysplasia, lymphoma, osteomyelitis and chondromyxoid fibroma. The radiological findings of the patient in the present study were nonspecific, in accordance with the literature. A biopsy of suspected osteolytic bone lesions is required to confirm diagnosis (8). The treatment of adult $\mathrm{LCH}$ cases depends on organ involvement and clinical course. Options include followup, local treatment, immunomodulation, irradiation, chemotherapy and allogeneic stem cell transplantation. The cessation of smoking is vital. Patients should be followed up for recurrence (8). In our patient, the mass was excised, including also intact bone and pleural tissue. The defect in the chest wall was reconstructed with mesh and a titanium plate to prevent flail chest or collapse.

In conclusion, single-site, single-system LCH in the rib is a rare bone tumor in adults that can be successfully treated with surgical interventions such as curettage or partial resection. A differential diagnosis of solitary osteolytic lesions in the rib should be considered.

\section{CONFLICTS OF INTEREST}

None declared.

\section{AUTHOR CONTRIBUTIONS}

Concept - M.Ç., A.F.D.; Planning and Design - M.Ç., A.F.D.; Supervision - M.Ç., A.F.D.; Funding -; Materials M.Ç.; Data Collection and/or Processing - M.Ç., A.F.D.; Analysis and/or Interpretation - M.Ç., A.F.D.; Literature Review - M.Ç.; Writing - M.Ç.; Critical Review - M.Ç.

\section{YAZAR KATKILARI}

Fikir - M.Ç., A.F.D.; Tasarım ve Dizayn - M.Ç., A.F.D.; Denetleme - M.Ç., A.F.D.; Kaynaklar -; Malzemeler M.Ç.; Veri Toplama ve/veya İşleme - M.Ç., A.F.D.; Analiz ve/veya Yorum - M.Ç., A.F.D.; Literatür Taraması M.Ç.; Yazıyı Yazan - M.Ç.; Eleştirel İnceleme - M.Ç.

\section{REFERENCES}

1. Stockschlaeder M, Sucker C. Adult Langerhans cell histiocytosis. Eur J Haematol 2006; 76:363-8. [CrossRef]

2. Postini AM, Andreacchio A, Boffano M, Pagano M, Brach Del PA, Fagioli F. Langerhans cell histiocytosis of bone in children: a long term retrospective study. J Pediatr Orthop B 2012;21:457-62. [CrossRef]

3. Abla O, Egeler RM, Weitzman S. Langerhans cell histiocytosis: current concepts and treatments. Cancer Treat $\operatorname{Rev} 2010 ; 36: 354-9$. [CrossRef]

4. Mavrogenis AF, Abati CN, Bosco G, Ruggieri P. Intralesional methylprednisolone for painful solitary eosinophilic granuloma of the appendicular skeleton in children. J Pediatr Orthop 2012; 32:416-22. [CrossRef]

5. Leonidas JC. Langerhans' cell histiocytosis. In: Taveras JM, Ferrucci JM, eds. Radiology: diagnosis, imaging, intervention. Vol 5. Philadelphia: Lippincott, 1990; 1-9.

6. Alexiou GA, Mpairamidis E, Sfakianos G, Prodromou N. Cranial unifocal Langerhans cell histiocytosis in children. J Pediatr Surg 2009; 44:571-4. [CrossRef]

7. Zaveri J, La Q, Yarmish G, Neuman J. More than Just Langerhans cell histiocytosis: a radiologic review of histiocytic disorders. Radiographics 2014; 34:2008-24. [CrossRef]

8. Girschikofsky M, Arico M, Castillo D, Chu A, Doberaver C, Fichter J, et al. Management of adult patients with Langerhans cell histiocytosis: recommendations from an expert panel on behalf of Euro- -Histio-Net. Orphanet J Rare Dis 2013; 8:72. [CrossRef] 